\title{
Human embryonic stem cells and clinical applications
}

\author{
Alan Colman ${ }^{1}$ \\ ${ }^{1}$ Executive Director, Singapore Stem Cell Consortium, A*STAR Institute of Medical Biology, Singapore
}

With the 2007 Nobel prize awards to Evans, Capecchi and Smithers, embryonic stem cell research has been rightly recognized for its enormous contributions towards increasing our understanding of mammalian development and disease. Much of this insight has arisen from the provision of mice knock out models. However, observations that the embryonic stem cell can be coaxed into a multitude of different cell types in vitro have also captured enormous attention. This matchless versatility is now being intensively exploited in human embryonic stem cells (hESC) with a view to providing partial or complete cures for a vast legion of troubling human ailments. Whilst the pluripotential nature of hESC offers the advantage, in principle, of allowing a wide choice of disease targets, the early developmental status of the cells makes efficient and correct differentiation into the desired adult cell types a difficult undertaking. In my lecture, I will explore the challenges and progress that accompany the translational efforts being made with hESC. In particular, I will survey progress towards clinical applications in the diabetes, congestive heart failure and spinal injury indications, paying attention to outstanding regulatory issues like safety and GMP compliance in this very difficult area of cell therapy. I will conclude that technical difficulties together with regulatory and investment concerns, are likely to impede clinical development of hESC cell therapy. However, I will also describe some recent research using conditioned media from hESCderived mesenchymal stem cells, that may provide a shorter timeline to the clinic.

Cell Research (2008) 18:s171. doi: 10.1038/cr.2008.261; published online 4 August 2008

Correspondence: Alan Colman

E-mail: alan.colman@imb.a-star.edu.sg

In July 2007, Alan Colman took the post of Executive Director of the Singapore Stem Cell Consortium and Principal Investigator at the A*STAR Institute of Medical Biology, having been with a private stem cell company, ES Cell International (ESI) since April 2002 (first CSO and then CEO). His main interests concern basic research into stem cells and the translation of that research into the clinic. Alan Colman obtained a BA degree in Biochemistry in Oxford (1971) and a PhD under John Gurdon, a pioneer of the field of nuclear transfer, at the Laboratory of Molecular Biology in Cambridge, UK (1974). After a series of academic appointments in Oxford and Warwick Universities, he became Professor of Biochemistry in the University of Birmingham, UK. The focus of his academic career was the area of eucaryotic protein secretion, with a particular emphasis on the use of frog oocytes and eggs as in vivo test tubes. From 1987 until March 2002, he was research director of the company PPL Therapeutics in Edinburgh, UK. This company specialized in the production of transgenic livestock that produced human therapeutic proteins in their milk PPL attracted considerable media attention because of their participation, together with the Roslin Institute, in the technique of somatic nuclear transfer. This work led to Dolly, the world's first sheep cloned from an adult somatic cell (1996), Polly and Molly, the first cloned transgenic livestock (1997), Diana and Cupid, the first livestock with targeted genetic changes (2000), Millie et al., the first cloned pigs (2000) and, finally, Austin and crew, the first homozygous, alpha gal transferase knock out pigs (2003)

Alan lists amongst his hobbies, mountain biking, scuba diving, white water rafting, skiing, and trying to approach old age gracefully. 